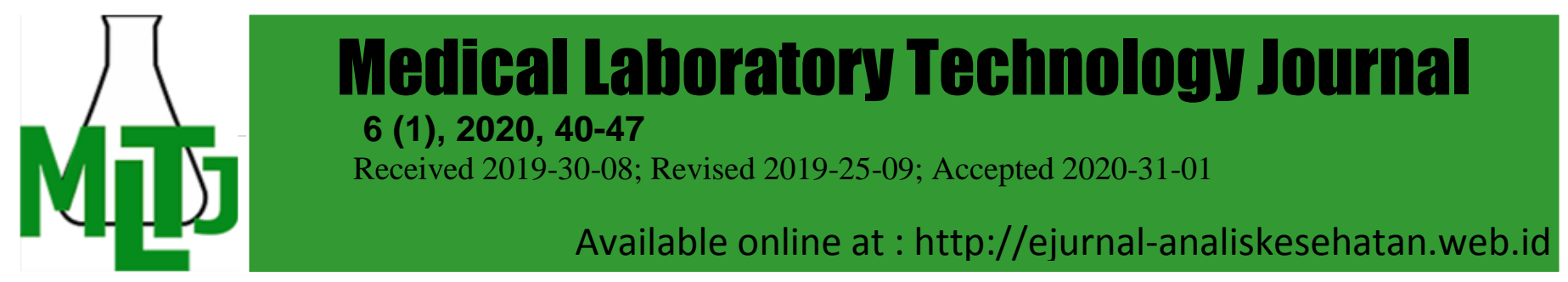

\title{
The Results of Toxoplasma gondii Examination IgM Antibodies Using ICT Method and ELISA Method in Pregnant Women
}

\author{
Syifa Amelia Nadayang, *Rizana Fajrunni’mah \\ Department of Medical Laboratory Technology Poltekkes Kemenkes Jakarta III \\ Jl. Arteri JORR Jatiwarna, Pondok Melati, Bekasi, West Java, Indonesia 17415 \\ *Email : rie.ners@gmail.com \\ DOI: 10.31964/mltj.v1i1.241
}

\begin{abstract}
Toxoplasmosis is a disease that can infect animals and zoonotic in humans. In pregnant women (congenital toxoplasmosis), the risk and severity of symptoms of congenital toxoplasmosis are more severe if infection occurs early in pregnancy and asymptomatic. The only way to determine disease is by serological screening. Serological diagnosis techniques for toxoplasmosis include ELISA (Enzyme-linked Immunosorbent Assay) and ICT (Immunochromatography Assay Test). However, until now, research on toxoplasmosis with the ICT method is still minimal. This study aims to analyze the results of the $\operatorname{lgM}$ antibody examination Toxoplasma gondii using the ICT method with the ELISA method and calculate the sensitivity and specificity of the ICT method and the ELISA method in pregnant women. The research design was used analytic (cross-sectional), with the number of samples is 33 serums. Data from the ELISA method obtained from secondary medical record data and the remaining serum samples were examined by the ICT method by researchers at the Harapan Kita Hospital Laboratory. In the ICT method, two samples (6.1\%) were positive, and 31 samples (93.9\%) were negative. In the ELISA method, results obtained similar to the ICT method, two samples $(6.1 \%)$ positive and 31 samples $(93.9 \%)$ with negative results. Toxoplasmosis examination can be done using the ICT method as the initial serological screening stage, but it not recommended as a diagnosis enforcer.
\end{abstract}

Keyword: Toxoplasma gondii; pregnant women; Enzyme-linked Immunosorbent Assay; Immunochromatography Assay Test

\section{INTRODUCTION}

Toxoplasmosis is a disease that can infect animals and zoonotic in humans. Toxoplasmosis caused by the parasite Toxoplasma gondii protozoa (Darmadi, Suratma, and Oka, 2012). Toxoplasmosis seroprevalence in humans in Indonesia ranges from $2 \%-63 \%$ with different figures in each region (Riyanda, 2017).

The definitive host of $T$. gondii is a cat, and its intermediate host is a warmblooded species, including humans, mammals, and poultry groups (Riyanda, 2017). Research conducted by Laksemi, Artama, and Wijayanti (2013) concluded that diet in the form of half-cooked meat consumption and fresh vegetables and soil contact work such as farming and gardening were significantly associated with toxoplasmosis. Toxoplasmosis can attack immunocompetent people (the immune system can respond optimally), with clinical manifestations only $10-12 \%$ with symptoms that are generally asymptomatic (without symptoms) or only mild and nonspecific symptoms appear (Yuliawati, Nasronudin, 2015).

Corresponding Author : Rizana Fajrunni'mah

Department of Medical Laboratory Technology Poltekkes Kemenkes Jakarta III. JI. Arteri JORR Jatiwarna, Pondok Melati, Bekasi, West Java, Indonesia 17415 Email : rie.ners@gmail.com 
If a woman has infected before becoming pregnant, the child she contains will be protected because the mother has developed immunity/antibodies. However, if a woman is pregnant and has just infected with $T$. gondii during pregnancy, she can transmit the infection to an unborn baby (congenital transmission) (Astuti, 2010). In pregnant women (congenital toxoplasmosis), the risk and severity of symptoms of congenital toxoplasmosis are more severe if infection occurs early in pregnancy. The classic triad of congenital toxoplasmosis is hydrocephalus, chorioretinitis, and intracranial calcification or sabin tetrad accompanied by psychomotor abnormalities. The involvement of neurological and ocular system problems often arises later on if it not found at birth (Yuliawati, Nasronudin, 2015).

Early detection of toxoplasmosis is complicated because mothers who suspected of suffering do not show clinical symptoms (Hanafiah et al., 2009). The only way to determine infection is by serological screening. This is a consideration of the need for serial screening and testing for every pregnant woman (Aryani, 2017). In the form of acute infection, $T$. gondii spreads to all organs, and the parasite disappears from the body in less than one week because of innate immunity and the emergence of specific immunity, including humoral immunity. IgM is the first antibody to appear, usually one week after infection (Alpiniawati, 2017). High IgM in women of reproductive age will increase the risk of congenital disease in infants if the woman is pregnant (Laksemi, Artama, Wijayanti, 2013).

Among several serological diagnosis techniques to date, only ELISA (Enzyme-linked Immunosorbent Assay) is capable of measuring quantitatively and can carry out testing for various purposes, which has been an essential weakness in the serological diagnosis of toxoplasmosis (Subekti, Artama, Iskandar, 2005). However, the diagnosis using ELISA is still expensive (Subekti, Artama, Iskandar, 2005) and requires a long test time or around 4-5 hours (Jin et al., 2005).

Method of ICT (Immunochromatography Assay Test) is a rapid diagnostic test that is qualitative based on immunochromatography (lateral flow) technology. This ICT method is easy to use and easy to interpret (LDBio Diagnostics, 2012). The advantages of this ICT method are fast and easy to use and do not require special equipment suitable for application in the field (Liu et al., 2015). In a study conducted in 2017 regarding the comparison of results between the ELISA and Rapid Test (ICT method) examination for HIV / AIDS screening, it was concluded that there was no difference between the ELISA examination method and Rapid Test (ICT method) seen from the same sensitivity and specificity (Dewi, 2017). But research on toxoplasmosis with the ELISA and ICT method is still unknown.

\section{MATERIALS AND METHODS}

This study is an analytical study with a cross-sectional approach conducted at the Laboratory of Anak Bunda Harapan Kita Hospital in the period February to April 2019. Poltekkes Kemenkes Jakarta III Ethics Commission approved this research with number KEPK-PKKJ3 / 36 / II / 2019 and Ethics Commission for Anak Bunda Harapan Kita Hospital by number IRB / 08/02 / ETIK / 2019. The population in this study were all pregnant women, who examined toxoplasmosis in Anak Bunda Harapan Kita Hospital. While the sample in this study were pregnant women who tested Toxoplasmosis IgM antibodies in Anak Bunda Harapan Kita Hospital with the amount of 33 serums. The sample size is determined based on proportion data from previous research using the following formula. 
$\mathrm{n}=\frac{\mathrm{Z}^{2} 1-\frac{a}{2} \times \mathrm{pq}}{\mathrm{d}^{2}}$

Information:

$\mathrm{n} \quad=$ Minimum sample size

$Z^{2} 1-\frac{a}{2}=Z$ table value according to the level of trust $(95 \%=1,96)$

$\mathrm{p}=$ = Proportion or prevalence based on the results of previous studies

$q \quad=1-p$

$\mathrm{d} \quad=$ Precision

Data on the results of $T$. gondii IgM antibody examination ELISA method is obtained from the results of laboratory tests and secondary medical records to determine pregnancy status then the remaining serum samples that have been examined by the ELISA method (Vidas Toxo $\lg \mathrm{M}$ ) are then analyzed by the ICT method (Shudabio) by researcher at Laboratory of Anak Bunda Harapan Kita Hospital.

The collected data checked for completeness of the data, coding, data tabulation, and data entry is carried out. The type of data obtained is categorical data by comparing positive and negative results between the two methods, then analyzed the sensitivity and specificity of ICT method.

\section{RESULTS AND DISCUSSION}

Table 1.Frequency Distribution of $T$. gondii IgM Antibody Results

\begin{tabular}{ccccc}
\hline \multirow{2}{*}{$\begin{array}{c}\text { ICT gondii IgM } \\
\text { Antibody Results }\end{array}$} & $\begin{array}{c}\text { Quantity } \\
(\mathrm{n})\end{array}$ & $\begin{array}{c}\text { Percentage } \\
(\%)\end{array}$ & $\begin{array}{c}\text { Quantity } \\
(\mathrm{n})\end{array}$ & $\begin{array}{c}\text { Percentage } \\
(\%)\end{array}$ \\
\hline Positive & 2 & 6.1 & 2 & 6.1 \\
Negative & 31 & 93.9 & 31 & 93.9 \\
Total & 33 & 100 & 33 & 100 \\
\hline
\end{tabular}

Examination of Toxoplasma gondii IgM antibodies performed on 33 serum samples of pregnant women in the Laboratory of Anak Bunda Harapan Kita Hospital using the ICT method. Before the examination utilizing the ICT method, 33 serum samples of pregnant women were examined using the ELISA method by the Laboratory of Anak Bunda Harapan Kita Hospital. The data obtained are then analyzed statistically.

Based on the results of the research obtained using the ICT method and the ELISA method, the results of the same percentage obtained where two samples $(6,1 \%)$ were positive for Toxoplasma gondii IgM antibodies. This is not much different from the study conducted by Uttah, Ogban, and Okonofua (2013) in Brazil, where it found that $3,26 \%$ of pregnant women tested positive for Toxoplasma gondii IgM antibodies. While the lower results obtained by Tolistiawaty et al. (2013), which the Toxoplasma gondii seropositivity for IgM antibodies in the town of Palu, just $0,7 \%$ using female respondents of childbearing age. In Indonesia, cumulatively 
cases of toxoplasmosis in humans serologically have a prevalence of more than 40\% (Pudjiatmoko et al., 2014).

This can be caused because IgM is the first antibody that appears, usually 1 week after infection. The number increases to peak after 1-3 months. The decline takes nine months to come until it is not detected (Alpiniawati, 2017). Along with the decrease in IgM levels, there is an increase in IgG levels at 1-2 weeks after infection and will continue to increase up to 6-8 weeks. Then it will last up to 1-2 years, even in some cases, and it will last a lifetime (Tolistiawaty et al., 2013).

Still, the presence of acute toxoplasmosis infection can cause due to the tropical climate in Indonesia where this climate is very suitable for the development of Toxoplasma gondii, besides that other factors can influence one of them is environmental sanitation (Fitriana, Pracoyo, 2017).

In pregnant women who get acute primary infection has a $50 \%$ chance of giving birth to a baby with congenital toxoplasmosis (Agustin, Mukono, 2015), which causes spontaneous abortion or children born to have congenital abnormalities. The classic triad of congenital toxoplasmosis includes chorioretinitis, intracranial calcification, and hydrocephalus (Aryani, 2017).

Based on the description above, this is a consideration of the need for serial toxoplasmosis screening and testing for every pregnant woman and premarital woman. Based on a survey by researchers at Anak Bunda Harapan Kita Hospital, we examined toxoplasma IgM in 2019 for Rp. 250,000 per patient. When compared with the ICT method which has a much lower price than the ELISA method, which is less than $\mathrm{Rp} 100,000$ per patient, the ICT method is more affordable and efficient for the community

Table 2. Sensitivity and Specificity of the ICT Method and ELISA Method

\begin{tabular}{cccc}
\hline \multirow{2}{*}{ ICT method } & \multicolumn{3}{c}{ ELISA method } \\
& Positive & Negative & Total \\
\hline Positive & 2 & 0 & 2 \\
Negative & 0 & 31 & 31 \\
\hline Total & 2 & 31 & 33 \\
\hline
\end{tabular}

Based on table 2, the calculation value of sensitivity, specificity, positive predictive value, negative predictive values are:

1. Sensitivity

$=\frac{2}{2+0} \times 100 \%=100 \%$

2. Specificity

$=\frac{31}{31+0} \times 100 \%=100 \%$

3. Positive predictive value

$=\frac{2}{2+0} \times 100 \%=100 \%$

4. Negative predictive value

$=\frac{31}{31+0} \times 100 \%=100 \%$

Based on table 4.3, the sensitivity value of the ICT method compared to the ELISA method is $100 \%$, the specificity value is $100 \%$, the positive predictive value is $100 \%$, and the negative predictive value is $100 \%$. This is similar to the research 
conducted by Dewi (2017) regarding the comparison of results between the ELISA and Rapid Test (ICT method) examination methods for HIV/AIDS screening, where the sensitivity value of the Rapid Test method (ICT method) and the ELISA method is $100 \%$. Likewise, for the specificity value of $100 \%$. This can cause because the ICT method has the ability of serological tests based on the ELISA technique, which is reported to have sensitivity and specificity that is equivalent to the ELISA technique in general (Subekti, Artama, Iskandar, 2005).

For positive predictive values and negative predictive values in this study following Dewi's research in 2017 , they were $100 \%$ and $100 \%$, respectively. This shows that truly positive patients have T. gondii IgM antibodies of $100 \%$, and genuinely negative patients have $T$. gondii IgM antibodies of $100 \%$.

Overall, both of these methods have advantages and disadvantages to each. The ELISA method is superior in measuring quantitatively and can determine antibody subclasses/immunoglobulin, cytokines, antigen detection, diagnosis of avidity, determination of infection status (acute or clinical), and even a combination with molecular diagnostic techniques can do well. Although it loaded with various advantages, the ELISA method also has weaknesses, namely high cost (especially for laboratories that rarely carry out routine diagnoses), especially if they require quantitative measurements (Subekti, Artama, Iskandar, 2005).

While the ICT method has an easy advantage in its use and is also easy to interpret (LDBio Diagnostics, 2012) and has sensitivity and specificity that is equivalent to the ELISA technique in general, however, the weakness of the immunochromatography technique is that it is not quantitative like ELISA (Subekti, Artama, Iskandar, 2005).

Although the results of the ICT method statistical tests in this study have significant differences compared to the ELISA method, but based on actual test results and analyses of sensitivity and specificity, the ICT method can be recommended as a screening test or initial serological screening for toxoplasmosis as well as other earlier examinations applying qualitative screening tests. Also, it hoped that this ICT method could use as one of the screening programs for pregnant women in health facilities that have small laboratories with limited equipment (clinics or health centers) so that congenital toxoplasmosis can be prevented and can improve the quality of human resources.

\section{CONCLUSION}

Based on the results of the research and discussion that has been described, it can be concluded that in the ICT method and the ELISA method the results obtained are similar in each technique, namely as many as 2 samples $(6,1 \%)$ with positive results and there are 31 samples (93.9\%) with negative results. As well as the sensitivity value of the ICT method compared to the ELISA method is $100 \%$, while the amount of the specificity of the ICT method compared to the ELISA method is $100 \%$. So Toxoplasmosis examination can be done using the ICT method as the initial serological screening stage but, it not recommended as a diagnosis enforcer.

\section{ACKNOWLEDGEMENT} Hospital.

Thanks to Poltekkes Kemenkes Jakarta III and Anak Bunda Harapan Kita

\section{CONFLICT OF INTEREST}

There were no conflicts of interest with related parties in this study. 


\section{REFERENCE}

Agustin, PD., Mukono, J. (2015). Description of Exposure to Cats with Toxoplasmosis in Cats and Non-Custodians in Mulyorejo District, Surabaya. Journal of Environmental Health, 8(1), 103-117.

Alpiniawati, NLPW. (2017). Toxoplasmosis in Pregnancy. Essay. Wijaya Kusuma University Surabaya. Surabaya.

Apsari, IAP, Artama, WT, Sumartono, Damriyasa, IM. (2012). Molecular Diagnosis of Toxoplasma gondii Based on Specific Stage Genes of Takizoit and Bradizoit in Kampung Chickens. Veterinary Journal, 13(1), 14-19.

Aryani, IGAD. (2017). Congenital toxoplasmosis. Continuing Medical Education CDK-255, 44(8), 537-539.

Astuti, NT. (2010). Toxoplasma gondii Nicolle \& Splendore 1908. Balaba All About Parasites, 6(01), 24 - 25.

BiomerieuX. (2010). Insert VIDAS TOXO IgM (TXM) kit. France.

Boster. (2017). How to Become an ELISA Expert in 4 days. Available from the URL: https://www.bosterbio.com/complete-elisa-guide-pdf. Downloaded June 2, 2018.

Darmadi, IP, Suratma, NA, and Oka, IBM. (2012). Relationship Between Antibody Titers and the Presence of Toxoplasma gondii Sista in Muscle and Pig Blood Tissue. Indonesia Medicus Veterinus, 1(5), 636-644.

Dewi, TIAS. (2017). Comparison of Results between the ELISA and Rapid Test Methods for HIV / AIDS Screening. Essay. Udayana University. Denpasar.

Fitriana, Pracoyo, NE. (2017). Detection of Toxoplasma gondiifrom Urine Specimens of HIV / AIDS Patients. Media Litbangkes, 27(2), 105-110.

Fristiani, AKB, Santosa, B., Ariyadi, T. (2017). Sensitivity and Specificity of HBsAg Rapid Test Method for ELISA. Thesis. Muhammadiyah University Semarang. Semarang.

Hanafiah, M., Nurcahyo, W., Kamaruddin, M., Karmil, F. (2009). Production and Isolation of Bradizoit Stadium Membrane Protein Toxoplasma gondii : An Effort to Obtain Diagnostic Material in Diagnosing Toxoplasmosis. Veterinary Journal, 10(3), 156-164.

Hangzhou Shuda Biotech. (2018). Insert Toxo IgG / IgM Kit for Cassette Rapid Test. China.

Indrawaty, S., Sosialine, E., Umar, F., Pahlemy, H., Andrajati, R., Rianti, A., et al. (2011). Clinical Data Interpretation Guidelines. Director-General of Pharmacy and Medical Devices Development, Ministry of Health Of The Republic of Indonesia. Jakarta. p:8

Iskandar, A., Mayashinta, DK., Sudjari, Indra, MR. (2018). Get to know Toxoplasma Gondii, Obesity, and Metabolic Syndrome. Malang: Universitas Brawijaya Press.

Jin, S., Chang, ZY, Ming, X., Min, CL, Wei, H., Sheng, LY, et al. (2005). Fast Dipstick Dye Immunoassay for Detection of Immunoglobulin G ( $\operatorname{lgG}$ ) and IgM Antibodies of Human Toxoplasmosis. Clinical and Diagnostic Laboratory Immunology, 12(1), 198-201

Krihariyani, D., Woelansari, ED, Kurniawan E. (2015). Seroprevalence of Toxoplasma gondii IgG Antibodies in Mothers in Rangkah 6 Surabaya.

Laksemi, DAAS, Artama, WT, and Wijayanti, MA. (2013). High Seroprevalence and Risk Factors of Toxoplasmosis in Blood Donors and Women in Bali. Veterinary Journal, 14(2), 204-212. 
LDBio Diagnostics. (2012). Instruction For Use Toxoplasma ICT IgG - IgM. Available from the URL: http://www.Idbiodiagnostics.com/fichiers_site/a1181ldb/contenu_pages/ict_toxo ab_V06_fr_en.pdf. Downloaded May 4, 2018.

Liu, Q., Wang, ZD, Huang, SY, and Zhu, XQ. (2015). Diagnosis of Toxoplasmosis and typing of Toxoplasma gondii. Biomed Central, 1-4. DOI No. $10.1186 /$ s13071-015-0902-6

Manik, AM, Oka, IBM ., Dwinata, IM. (2013). Bioassay of Toxoplasma gondii in Cats. Indonesia Medicus Veterinus, 2(1), 12-31.

Oktariana, AW. (2014). Risk Factors Against Toxoplasmosis Occurrence in Women of Childbearing Age at Assalam Gemolong Hospital in Sragen Regency. Essay. Muhammadiyah Surakarta University. Surakarta.

Regulation of the Minister of Health of the Republic of Indonesia Number 59 of 2013 concerning Implementation of Laboratory Examinations for Pregnant, Maternity and Postpartum. $p: 22$.

Pratama, DAOA, Sumartono, Artama, WT. (2009). Analysis of Toxoplasma Gondii Repeat Region 529 bp (NCBI Acc. No. AF146527) as a Candidate Probe for Molecular Diagnosis of Toxoplasmosis. Indonesian Journal of Biotechnology, 14(1), 1124-1131.

Pudjiatmoko, Syibli, M., Nurtanto, S., Lubis, N., Syafrison, Yulianti, S., et al. (2014). Manual of Mammal Animal Diseases. 2nd Print. Sub-Directorate of Animal Disease Observation, Directorate of Animal Health, Directorate General of Animal Husbandry and Animal Health, Ministry of Agriculture. Jakarta. $p$ : 460-468.

Riyanda, APP. (2017). Seroprevalence of Toxoplasma gondii in Goat Livestock in Bandar Lampung City. Essay. The University of Lampung. Bandar Lampung.

Sari, BRY, and Gugun, AM. (2014). Prevalence of IgM / IgG Seropositive Toxoplasm in Premarital Women and Review of Risk Factors for Cat Ownership. Mutiara Medika, 14(1), 1-7.

Sastroasmoro, S., Ismael, S. (2014). Basics of Clinical Research Methodology. (Fifth edition). Jakarta: CV Sagung Seto.

Siregar, RY, Yuswandi. (2014). Prevalence of Toxoplasmosis in Slaughtered Sheep in Yogyakarta's RP RPH using the CATT Method. Veterinary Science Journal, 32(1), 78-84.

Soedarto. (2012). Toxoplasmosis Prevents and Overcomes Disease Protecting Mother and Child. Jakarta: Sagung Seto.

Subekti, DT, Kusumaningtyas, E. (2011). Comparison of Toxoplasmosis Serological Test with Immunostic Rapid Test, ELISA and Latex Agglutination. JITV, 16(3), 224-233.

Subekti, DT, Arrasyid, NK. (2006). Immunopathogenesis of Toxoplasma Gondii Based on Differences in Strains. Wartazoa, 16(3), 126 - 145.

Subekti, DT, Artama, WT, Iskandar, T. (2005). Case Development and Technology for Diagnosing Toxoplasmosis. National Zoonotic Disease Workshop. Page: 253-264.

Sukma, IGNA. (2015). Description of the existence of Toxoplasma gondii in Lake Water and the Risk of Toxoplasmosis Behavior of Communities Around the Lake in Bali in 2015. Essay.Udayana University. Denpasar.

Suparman, E. (2012). Toxoplasmosis in Pregnancy. Biomedical Journal, 4(1), 13-19. 
Suryadi, Y., Manzila, I., Machmud, M. (2009). Potential Utilization of ELISA Diagnostic Devices and Their Variants for Plant Pathogen Detection. Agro Biogen, 5(1), 39-48.

Tolistiawaty, I., Rosmini, Suarayasa, K., Gunawan, Sumolang, PPF. (2013). Toxoplasmosis Serology description of Eligible Women in Eight health centers in the city of Palu. Disease Vector Journal, 7(2), 35-39.

Torgerson, PR, Mastroiacovo, P. (2013). The Global Burden of Congenital Toxoplasmosis: A Systematic Review. Bull World Health Organ, (91), 501-508.

Uttah, E., Ogban, E., Okonofua, C. (2013). Toxoplasmosis: A Global Infection So Spreads So Neglected. International Journal of Scientific and Research Publications, 3(6), 1-6.

Weiss, LM, Kim, K. (2014). Toxoplasma gondii: the composite models of perspectives and methods. (Edition 2). San Diego: Academic Press, Elsevier. Pages: 2.

WHO. (2015). Toxoplasmosis Fact Sheet. Available from the URL: http://www.euro.who.int/_data/assets/pdf_file/0011/294599/FactsheetToxoplasmosis-en.pdf. Downloaded February 21, 2018.

Yuliawati, I., Nasronudin. (2015). Pathogenesis, Diagnostic and Management of Toxoplasmosis. Indonesian Journal of Tropical and Infectious Disease, 5(4), 100-106.

Yurisma, R. (2013). Overview of Eligible Spouse Knowledge About Toxoplasma gondii Infection In the village Peuniti Baiturrahman District of Banda Aceh. Essay. Banda 